\title{
KAJIAN JENIS BAHAN PEMBAWA DAN LAMA SIMPAN TERHADAP INFEKTIVITAS DAN EFEKTIVITAS INOKULAN FUNGI MIKORIZAARBUSKULA
}

\section{STUDY OF THE TYPES OF CARRIERS AND TIME OF STORAGE ON THE INFECTIVITY AND EFFECTIVENESS OF ARBUSCULAR MYCORRHIZAL FUNGAL INOCULANT}

\author{
Lily F. Ishaq ${ }^{1}$, D. R. Lukiwati ${ }^{2}$, Yoke I. Benggu ${ }^{1}$, Peters O. Bako ${ }^{1}$ \\ ${ }^{1}$ Program Studi Agroteknologi Fakultas Pertanian Universitas Nusa Cendana \\ ${ }^{2}$ Fakultas Peternakan dan Pertanian Universitas Diponegoro \\ *Email: lily.ishaq@yahoo.com \\ * Corresponding Author, Diterima: 15 Des. 2020, Direvisi: 5 Mei 2021, Disetujui: 21 Mei 2021
}

\begin{abstract}
Arbuscular mycorrhizal fungi (AMF) have many benefits and have the potential to be developed as biological fertilizers in the dry land of East Nusa Tenggara. One way of storing AMF before application is packaging in capsule form. The type of carrier and its ability to maintain AMF infectivity and effectivity during storage are the factors that determine the success of using AMF capsules. This study aimed to examine the types of carriers and time of storage on the infectivity and effectiveness of AMF. This research was a two factors field experiment laid out in a split plot design. The main plot was a type of carrier material consisted of three levels, namely husk charcoal, zeolite and limestone, while the sub-plot was time of storage consisted of 2 levels, namely 4 months and 6 months of storage. The AM fungal spores used as inoculants were indigenous AMF collection obtained from the maize rhizosfer. The variables observed included the number of spores / $100 \mathrm{~g}$ of soil, root colonization, tissue P content, plant biomass dry weight and cob weight. The results showed that there was a significant interaction between the type of carrier material and the time of storage on root colonization and plant tissue P. However, the type of carrier material and time of storage did not significantly affect the number of AMF spores, plant biomass dry weight and cobs weight. This indicated that husk charcoal, zeoiite and limestone have the potential to be used as AMF inoculant carriers.
\end{abstract}

Keywords: Arbuscular mycorrhizal fungi, carrier, storage time.

\begin{abstract}
ABSTRAK
Fungi mikoriza arbuskula (FMA) memiliki banyak manfaat dan berpotensi untuk dikembangkan sebagai pupuk hayati di lahan kering iklim kering Nusa Tenggara Timur. Salah satu cara penyimpanan FMAsebelum diaplikasikan adalah pengemasan dalam bentuk kapsul. Jenis bahan pembawa dan kemampuannya dalam mempertahankan infektivitas dan efektivitas FMA selama masa penyimpanan merupakan faktor yang menentukan keberhasilan penggunaan kapsul FMA. Penelitian ini bertujuan untuk mengkaji jenis bahan pembawa dan lama simpan terhadap infektivitas dan efektivitas FMA. Penelitian ini merupakan percobaan lapangan yang didesain dalam bentuk percobaan faktorial dua faktor dengan menggunakan rancangan petak terpisah (split plot). Sebagai petak utama
\end{abstract}


adalah jenis bahan pembawa yang terdiri dari tiga taraf yaitu arang sekam, zeolit dan gamping, sedangkan anak petak adalah lama simpan yang terdiri dari 2 taraf yaitu lama simpan 4 bulan dan 6 bulan. Spora yang digunakan sebagai inokulan adalah FMA indigen hasil koleksi yang diperoleh dari rhizofer jagung. Variabel yang diamati terdiri dari jumlah spora/ $100 \mathrm{~g}$ tanah, tingkat infeksi akar, kandungan Pjaringan, berat kering biomassa tanaman dan bobot tongkol. Hasil penelitian menunjukkan terdapat interaksi yang nyata antara jenis bahan pembawa dan lama simpan terhadap kolonisasi akar dan P jaringan tanaman. Meskipun demikian, jenis bahan pembawa dan lama simpan tidak berpengaruh nyata terhadap jumlah spora FMA, bobot kering biomassa dan bobot tongkol. Hal ini menunjukkan arang sekam, zeoiit dan gamping berpotensi untuk dijadikan sebagai bahan pembawa inokulan FMA.

Kata kunci : Bahan pembawa, fungi mikoriza arbuskula, lama simpan.

\section{PENDAHULUAN}

Lahan kering iklim kering Nusa Tenggara Timur (NTT) tergolong lahan sub-optimal yang membutuhkan pengelolaan khusus untuk peningkatan produktivitasnya. Hingga saat ini upaya peningkatan produktivitas tanaman pada lahan kering NTT, termasuk jagung yang merupakan salah satu tanaman pangan utama setelah padi, masih mengandalkan penggunaan pupuk anorganik. Di sisi lainnya, penggunaan pupuk anorganik tidak selalu efektif dan efisien dengan kondisi lahan yang ada. Selain itu, penggunaan pupuk anorganik dalam jangka panjang dapat berdampak pada penurunan kualitas lahan atau dampak lingkungan lainnya.

Terkait dengan kondisi lahan kering NTT, khususnya Pulau Timor yang sebagian besar tanahnya terbentuk dari batuan kapur, penggunaan pupuk hayati mikoriza arbuskula dapat menjadi salah satu alternatif untuk peningkatan produktivitas tanaman. Mikoriza arbuskula merupakan hubungan simbiosis mutualisme antara jamur dan akar tanaman dimana dalam hubungan simbiosis ini mikoriza memperoleh karbohidrat dari inangnya, dan sebaliknya mikoriza memberi berbagai keuntungan kepada inangnya (Smith and Read, 2008) seperti meningkatkan pertumbuhan tanaman dan membantu penyerapan hara (Marschner and Dell, 1994; Farzaneh et al. 2011), meningkatkan ketahanan tanaman terhadap kondisi abiotik yang kurang menguntungkan seperti kekeringan (Al-Karaki et al., 2003; Rapparini and Penuelas, 2014), salinitas (Fang et al. 2002; Garg and Pandey, 2015), logam berat (Luo et al. 2017) dan dapat memperbaiki struktur tanah (Muchane et al., 2013).

Fungi mikoriza arbuskula merupakan tipe mikoriza yang paling luas penyebarannya dan dapat membentuk kolonisasi dengan berbagai jenis tanaman (Srinberg and Rillig, 2003; Smith and Read, 2008). Efektivitas fungi mikoriza arbuskula (FMA) dalam meningkatkan pertumbuhan tanaman dapat dipengaruhi oleh kemampuan FMA dalam beradaptasi terhadap kondisi setempat. FMA indigen yang telah beradaptasi dengan kondisi setempatkemungkinan akan lebih efektif dalam meningkatkan pertumbuhan tanaman dibandingkan dengan FMA eksogen (Pellegrino et al., 2011). Hasil penelitian sebelumnya menunjukkan sejumlah FMA indigen dapat ditemukan pada rhizosfer jagung pada akhir musim hujan (Ishaq et al., 2017) maupun pada saat musim kemarau (Ishaq, 2018), 
Salah satu bentuk pemanfaatan FMA sebagai pupuk hayati adalah pengemasan dalam bentuk kapsul yang mengandung propagul FMA. Propagul FMA dapat berupa spora, hifa dan akar yang terinfeksi, namun spora FMA merupakan propagul yang mampu bertahan hidup lebih lama dibandingkan dengan hifa yang ada di dalam akar ataupun di dalam tanah (Smith and Read, 2008). penggunaan spora sebagai inokulan lebih mengurangi resiko kontaminasi dibandingkan propagul lainnya. Untuk pengemasan spora FMA dalam bentuk kapsul dibutuhkan bahan pembawa yaitu suatu bahan yang digunakan sebagai tempat hidup inokulan sebelum diaplikasikan. Jenis bahan pembawa yang digunakan dan lama penyimpanan spora FMA yang dikemas dalam bentuk kapsul akan mempengaruhi viabilitas spora FMA seperti daya infeksi, jumlah propagul maupun efektivitasnya setelah diaplikasikan ke tanaman. Kriteria bahan pembawa yang baik diantaranya adalah memiliki aerasi yang baik, mudah disterilisasi, tidak beracun, daya simpan yang lama dan mampu mempertahankan viabilitas mikroba yang ada. Bahan-bahan ini dapat berupa bahan organik dan bahan anorganik atau sintetik (Maria and Felinov, 2017). Zeolit merupakan bahan yang sering digunakan sebagai pembawa mikoriza, namun bahan lain yang dapat digunakan dapat berupa tanah (Anwaruddin dkk. 2004), campuran zeolit dan arang sekam (Nurbaity dkk. 2009; 2011) dan campuran zeolit dengan bahan lain berupa tanah dan pasir (Siregar dkk. 2020). Batuan gamping merupakan mineral yang banyak ditemukan di Pulau Timor, namun belum banyak diteliti mengenai potensinya sebagai bahan pembawa mikoriza arbuskula. Penelitian ini dilakukan dengan tujuan untuk mengkaji jenis bahan pembawa FMA dengan lama simpan yang mampu mempertahankan infektivitas dan efektivitas FMA.

\section{BAHAN DAN METODE}

\section{Tempat dan waktu}

Penelitian ini telah dilaksanakan pada lahan pertanian di Desa Penfui Barat, Kecamatan Taebenu, Kabupatan Kupang, Provinsi Nusa Tenggara Timur (NTT). Pengamatan FMA dilakukan di Laboraturium Penyakit Tumbuhan dan Laboraturium UPT Lahan Kering, sedangkan analisis sifat tanah dilakukan di Laboratorium Kimia Tanah Faperta Universitas Nusa Cendana. Penelitian berlangsung dari bulan September 2018 sampai bulan Juni 2019.

\section{Bahan dan Alat Penelitian}

Bahan-bahan yang digunakan diantaranya adalah sampel tanah, sampel akar, benih jagung, plastik sampel, pupuk SP-36, pupuk urea, pupuk $\mathrm{KCl}$, sukrosa $60 \%$, aquades, tissu, air, alkohol 70\%, kertas saring Whatman nomor 41, aluminium foil, asam laktat, ethanol 50\%, $\mathrm{KOH} \mathrm{10 \% ,} \mathrm{glyserol,} \mathrm{0,05 \%} \mathrm{trypan} \mathrm{blue}$ (dalam lactoglycerol), kapsul, amplop besar.

Peralatan yang digunakan adalah parang, linggis, traktor tangan, meteran, kamera, mikroskop, saringan berbagai ukuran $(500 \mu \mathrm{m}, 297 \mu \mathrm{m}, 150 \mu \mathrm{m}$ dan 45 $\mu \mathrm{m})$, cawan petri, pipet halus, timbangan digital, timbangan analitik, sentrifuse, penyaring porselen, syringe $50 \mathrm{ml}$, gelas beaker, oven, autoclave, ember, hotplate, dan alat tulis menulis.

\section{Metode Penelitian}

Penelitian ini merupakan penelitian ekperimental yang dirancang sebagai percobaan faktorial dua faktor 
dengan menggunakan Rancangan Petak Terpisah (Split Plot Design) dalam rancangan dasar Rancangan Acak Kelompok. Pemblokan dilakukan dengan memotong arah datang sinar matahari. Dalam penelitian ini, sebagai petak utama adalah jenis bahan pembawa $(C)$ yang terdiri dari 3 taraf yaitu: $\left(\mathrm{C}_{1}\right)$ arang sekam $\left(\mathrm{C}_{1}\right)$, zeolit $\left(\mathrm{C}_{2}\right)$, dan batuan gamping $\left(\mathrm{C}_{3}\right)$, sedangkan sebagai anak petak adalah perlakuan lama simpan (T) yang terdiri dari 2 level yaitu lama simpan 4 bulan $\left(\mathrm{T}_{1}\right)$ dan lama simpan 6 bulan $\left(\mathrm{T}_{2}\right)$.

Setiap percobaan dibuat dalam 3 ulangan sehingga diperoleh 18 satuan percobaan. Pengacakan dilakukan terhadap perlakuan bahan pembawa pada petak utama (PU) dan dilanjutkan dengan perlakuan lama simpan spora sebagai anak petak (AP).

\section{Penyiapan Inokulum Spora FMA}

Inokulum spora FMA yang dipakai dalam penelitian ini adalah spora mikoriza tipe campuran (Glomus sp.) yang diisolasi dari hasil penelitian sebelumnya yang menggunakan tanaman inang jagung (Ishaq et al., 2017). Ciri morfologi spora FMA yang digunakan yaitu berwarna kuning dan putih, bentuk bulat dan permukaan halus. Isolasi spora dilakukan dengan metode penyaringan basah bertingkat (wet sieving) dengan ukuran saringan $500 \mu \mathrm{m}, 297 \mu \mathrm{m}, 150$ $\mu \mathrm{m}$ dan $45 \mu \mathrm{m}$. Spora hasil isolasi ditempatkan pada potongan-potongan kertas $\operatorname{kecil}(0,5 \times 0,5 \mathrm{~cm})$ dalam cawan petri yang telah dilapisi kertas saring. Setiap potongan kertas berisi 50 spora FMA.

\section{Penyiapan Bahan Pembawa (Carrier)}

Bahan pembawa (zeolit komersil untuk pertanian dengan ukuran partikel 2-3 mm, sekam padi yang sudah disangrai dan batuan gampiing) dihaluskan dengan menggunakan mortar porselen, kemudian disaring menggunakan saringan berukuran $300 \mu \mathrm{m}$. Bahan-bahan ini kemudian dimasukan ke dalam plastik tahan panas dan disterilkan dengan autoklaf selama 10 menit dengan suhu $121^{\circ} \mathrm{C}$ dan tekanan $1 \mathrm{~atm}$. Setelah disterilkan, bahan pembawa ini ditempatkan dalam cawan petri dan dikeringanginkan hingga cukup kering, dan disimpan dalam desikator sebelum digunakan.

\section{Pengemasan dan Penyimpanan Kapsul.}

Potongan kertas yang berisi spora FMA yang diuji dimasukan ke dalam kapsul dengan menggunakan pinset, bahan pembawa (arang sekam, zeolit dan batuan gamping yang sudah disteril dan dikeringanginkan) lalu dimasukan ke dalam kapsul tersebut hingga hampir penuh kemudian kapsul ditutup. Kapsul berisi spora dan bahan pembawa dikocok selama 1 menit agar spora tercampur merata dengan bahan pembawanya. Kapsul berisi spora ini kemudian dimasukan ke dalam plastik berpenutup (ziplock) yang telah diberi label sesuai dengan perlakuan dan disimpan dalam laboratorium pada suhu ruangan.

Perlakuan dengan lama simpan 6 bulan dikemas lebih awal ( 2 bulan lebih awal sebelum perlakuan lama simpan 4 bulan) sehingga aplikasi dapat dilakukan pada waktu yang bersamaan saat tanam. Spora yang digunakan untuk perlakuan lama simpan 6 bulan diisolasi dari sampel tanah pada pot-pot kultur perbanyakan 1-4 hari sebelum dikemas. Demikian pula untuk spora yang digunakan untuk penyimpanan 4 bulan .

\section{Penyiapan Lahan}

Lahan yang digunakan untuk penelitian adalah merupakan lahan tidur dengan vegetasi semak dan rumput. Sebelum dibersihkan, dilakukan pengambilan 
sampel tanah komposit untuk analisis sifat kimia tanah dan isolasi spora awal. Lahan selanjutnya dibersihkan, diolah menggunakan traktor tangan (hand tractor) kemudian dibuat blok-blok percobaan. Pada masingmasing blok dibentuk 6 petak percobaan dengan ukuran masing-masing $2 \mathrm{~m} \times 1.5 \mathrm{~m}$, jarak antar blok $1.5 \mathrm{~m}$, jarak antara anak petak adalah $0.8 \mathrm{~m}$ dan jarak antara petak utama adalah $1.5 \mathrm{~m}$. Jarak tanam yang dipakai adalah $50 \mathrm{~cm}$ x $50 \mathrm{~cm}$. Penempatan perlakuan dalam petak utama dan anak petak dilakukan secara acak sederhana menggunakan lotre.

\section{Penanaman dan Inokulasi Spora FMA}

Benih jagung manis varietas super sweety (umur panen 60-75 hari) dicuci dengan air destilasi untuk membersihkan insektisida yang melekat pada benih. Inokulasi FMA dilakukan saat tanam. Untuk setiap petak percobaan, inokulasi FMA dilakukan pada 2 tanaman yang yang terletak di tengah petak percobaan dan dijadikan sebagai tanaman sampel. Inokulasi kapsul FMA dilakukan dengan cara berlapis (tanah-sporatanah-benih-tanah). Lubang tanam dibuat sedalam 7$10 \mathrm{~cm}$, kapsul dibuka dan isi kapsul disebar merata pada lubang tanam, disiram secukupnya lalu ditimbun dengan tanah setebal sekitar $3 \mathrm{~cm}$. Selanjutnya benih ( 2 benih) ditempatkan pada lubang tanam tersebut dan ditimbun dengan tanah.

Untuk inokulasi, kapsul berisi spora FMA dapat langsung diaplikasikan, namun dalam penelitian ini, kapsul berisi spora sengaja dibuka saat diaplikasikan dengan tujuan agar spora lebih tersebar merata dalam lubang tanam sehingga peluang kontak dengan akar tanaman juga lebih merata.

Pada saat tanaman berumuran 2 minggu dilakukan penjarangan dan pemupukan. Pupuk dasar NPK diberikan dengan dosis $50 \%$ dari dosis anjuran untuk tanaman jagung yaitu: urea 1 g.tan ${ }^{-1}$, SP36 2,5 g.tan ${ }^{-1}, \mathrm{KCl} 0,75$ g.tan ${ }^{-1}$. Aplikasi pupuk dilakukan dengan cara pembenaman di sekitar lubang tanam lalu ditimbun dengan tanah. Penjarangan dilakukan saat pemupukan yang dibuat untuk menyisakan 1 dari 2 tanaman yang sehat.

\section{Pemeliharaan Tanaman}

Penyiraman dilakukan setiap hari menggunakan dinamo dengan waktu penyiraman diatur seragam untuk setiap bedengan..Penyiangan dilakukan secara manual. Pada awal tanam, benih diserang oleh hama semut dan dilakukan pengendalian dengan menggunakan Furadan dan. pada umur 32 hari setelah tanam (HST), tanaman terserang hama kumbang dan dilakukan pengendalian menggunakan Sangrabus.

\section{Pemanenan}

Pada saat tanaman mulai memasuki masa berbunga, diambil sampel daun (daun ketiga membuka sempurna) untuk analisis $\mathrm{P}$ jaringan. Pemanenan dilakukan saat tongkol telah berisi (75 HST). Sampel tanah dan akar diambil di sekitar perakaran tanaman untuk pengamatan FMA. Pengamatan jumlah spora FMA tanah dilakukan dengan metode penyaringan basah (wet sieving). Pengamatan tingkat infeksi akar dilakukan dengan metode pewarnaan (clearing and staining), dan perhitungan tingkat infeksi akar dilakukan dengan metode gridline intersection (Brundrett et al. 1996).

\section{Analisis Data}

Data hasil pengamatan dianalisis dengan ANOVA dan dilanjutkan dengan uji lanjut DMRT (Duncan Multi Range Test) pada taraf alfa 5\%. 


\section{HASIL DAN PEMBAHASAN}

\section{Sifat Tanah}

Hasil analisis sifat tanah awal menunjukkan lahan yang digunakan dalam penelitian memiliki kandungan $\mathrm{C}$ organik yang rendah $(1,8 \%), \mathrm{N}$ total tergolong rendah $(0,12 \%), \mathrm{P}$ tersedia sangat rendah $\left(6,4 \mathrm{mg} \cdot \mathrm{kg}^{-1}\right), \mathrm{P}$ total tergolong tinggi $\left(97,3 \mathrm{mg} \cdot \mathrm{kg}^{-1}\right)$, $\mathrm{K}$ dapat tukar tergolong sedang $\left(0,56 \mathrm{Cmol} . \mathrm{kg}^{-1}\right), \mathrm{pH}$ tanah tergolong masam $(5,53)$, kapasitas tukar kation (KTK) tergolong tinggi, dan tekstur tanah adalah lempung berliat (Tabel 1). Kandungan bahan organik tanah berkaitan dengan pengembalian bahan organik ke tanah. Kandungan bahan organik umumnya juga mempengaruhi kandungan $\mathrm{N}$ total tanah terutamajika sumber bahan organik yang dikembalikan ke tanah memilki kandungan hara $\mathrm{N}$ jaringan yang tinggi. Ketersediian P pada tanah-tanah di Timor umumnya rendah walaupun memilki kandungan $P$ total tanah yang umumnya sangat tinggi. Hal ini disebabkan karena terjadinya fiksasi P oleh Ca. Tanah-tanah di Timor terbentuk dari bahan induk kapur dengan kandungan Ca yang tinggi yang dapat memfiksasi $\mathrm{P}$ sehingga menjadi tidak larut dan tidak tersedia bagi tanaman (Brady and Weil, 2000; Leytem and Mikkelsen, 2005)). Kalium dapat tukar yang tergolong sedang, hal ini kemungkinan berkaitan dengan mineral-mineral yang ada dan timgkat pencucian yang rendah. $\mathrm{pH}$ tanah yang tergolong rendah kemungkinan disebabkan karena lahan tersebut sering tergenang air yang mana hal ini didukung dengan tekstur tanah yang memiiliki kandungan liat yang cukup tinggi. Kapasitas tukar kation tergolong tinggi. Salah satu faktor yang mempengaruhi KTK adalah kandungan liat. Tanah dengan kandungan liat yang tinggi terutama liat montmorilonit, umumnya memilki KTK yang tinggi (Brady and Weil, 2000)

\section{Jumlah spora FMA}

Hasil analisis statistik menunjukkan jenis bahan pembawa zeolit, arang sekam dan gamping dengan masa penyimpanan 4 dan 6 bulan tidak berpengaruh nyata terhadap jumlah spora setelah diaplikasikan ke tanaman (Tabel 4). Hal ini menunjukkan bahwa bahan pembawa yang diuji mampu mempertahankan viabilitas spora selama masa penyimpanan sehingga spora FMA mampu berkecambah dan memperbanyak diri setelah diaplikasikan ke tanaman. Tidak nyatanya perlakuan jenis bahan pembawa dan lama simpan yang diuji menunjukkan zeolit, arang sekam dan gamping mampu mempertahankan viabilitas spora FMA dengan masa penyimpanan 4 dan 6 bulan.

Pada penelitian ini rerata jumlah spora yang diperoleh berkisar 321-529 per 100 gram tanah, dan bila dibandingkan dengan data awal jumlah spora pada lokasi penelitian sebelum dilakukan percobaan yaitu 1530 spora/100 gram tanah, maka terjadi peningkatan jumlah spora akibat perlakuan yang diberikan. Hal ini menunjukkan walaupun kemungkinan terjadi kompetisi

Tabel 1. Hasil analisis sifat tanah awal

\begin{tabular}{cccccccc}
\hline $\begin{array}{c}\text { C-organik } \\
(\%)\end{array}$ & $\begin{array}{c}\text { N-total } \\
(\%)\end{array}$ & $\begin{array}{c}\text { P-tersedia } \\
\left(\mathrm{mg}^{\circ} \mathrm{kg}^{-1}\right)\end{array}$ & $\begin{array}{c}\text { P-Total } \\
\left(\mathrm{mg} \cdot \mathrm{kg}^{-1}\right)\end{array}$ & $\begin{array}{c}\text { K-dd } \\
\left(\mathrm{Cmol}^{\circ} \mathrm{kg}^{-1}\right)\end{array}$ & $\begin{array}{c}\mathrm{pH} \\
\left(\mathrm{H}_{2} 0\right)\end{array}$ & $\begin{array}{c}\text { KTK } \\
\left.\left(\mathrm{Cmol}_{\mathrm{kg}}\right)^{-1}\right)\end{array}$ & Tekstur \\
\hline $1,8(\mathrm{R})$ & $0,12(\mathrm{R})$ & $6,4(\mathrm{SR})$ & $97,3(\mathrm{ST})$ & $0,56(\mathrm{~S})$ & $5,53(\mathrm{M})$ & $31,52(\mathrm{~T})$ & $\mathrm{LB}$ \\
\hline
\end{tabular}

$\mathrm{SR}=$ sangat rendah; $\mathrm{R}=$ Rendah; $\mathrm{S}=$ sedang; $\mathrm{T}=$ tiinggi; $\mathrm{ST}=$ sangat tinggi; $\mathrm{M}=$ masam; $\mathrm{LB}=$ lempung berliat 
antara spora yang diinokulasi dan spora asli lahan, tingkat perkembangan spora yang ada menunjukkan spora yang diinokulasi mampu berkompetisi dengan baik. Menurut Brundrett (1992), beberapa isolat FMA mampu manjadi kompetitor yang lebih baik dibandingkan dengan isolat FMA lainnya. Spora FMA yang diinokulasi merupakan spora yang diisolasi dari rhizosfer jagung sehingga kemungkinan mempunyai daya saing dan kompatibilitas yang lebih tinggi dibanding spora asli lahan.

\section{Tingkat kolonisasi akar}

Hasil analisis statistik menunjukkan terdapat interaksi yang nyata antara jenis bahan pembawa dan lama simpan terhadap tingkat kolonisasi akar. Pada lama simpan 4 bulan, bahan pembawa arang sekam memberikan presentase kolonisasi akar yang lebih tinggi dibandingkan bahan pembawa zeolit dan gamping. Sedangkan pada lama simpan 6 bulan, zeolit cenderung memberikan presentase kolonisasi akar yang lebih tingi dibandingkan dengan bahan pembawa arang sekam dan gamping. Bahan pembawa gamping cenderung tidak jauh berbeda pada lama simpan 4 dan 6 bulan (Tabel 2).
Data ini menunjukkan tingkat infektivitas FMA yang diaplikasikan ke tanaman setelah disimpan dapat dipengaruhi oleh jenis bahan pembawa dan periode lama simpan.

Pada penelitian ini diperoleh jenis bahan pembawa dengan lama simpan yang berbeda memberikan pengaruh yang berbeda terhadap infektivitas FMA. Pada periode 6 bulan, bahan zeolit memberikan infektivitas FMA yang lebih baik sedangkan pada lama simpan 4 bulan arang sekam memberikan infektivitas yang lebih baik. Hasil penelitian sebelumnya menunjukkan jenis bahan pembawa dapat mempengaruhi presentase kolonisasi akar (Syah dkk. 2004), demikian pula masa simpan spora FMA dapat mempengaruhi infektivitas spora setelah diaplikasikan (Maria dkk., 2020). Sifat bahan pembawa sangat menentukan kondisi internal bahan tersebut dalam mempertahankan viabilitas mikroba selama masa penyimpanan. Beberapa sifat bahan pembawa yang baik diantaranya adalah bersifat porus atau memiliki aerasi yang baik, mudah diperoleh dan disterilisasi (Maria and Felinov, 2017), dan ketiga bahan yang diuji

Tabel 2. Presentase kolonisasi FMA yang dikemas menggunakan beberapa jenis bahan pembawa dengan lama simpan yang berbeda pada akar tanaman jagung

\begin{tabular}{|c|c|c|c|}
\hline \multirow{2}{*}{ Jenis Bahan Pembawa } & \multicolumn{2}{|c|}{ Lama Simpan } & \multirow{2}{*}{ Rerata } \\
\hline & 4 bulan & 6 bulan & \\
\hline & \multicolumn{2}{|c|}{ Tingkat Infeksi Akar (\%) } & \\
\hline Zeolit & $\begin{array}{c}54,07 \text { a } \\
\text { A }\end{array}$ & $\begin{array}{c}61,97 \mathrm{~b} \\
\mathrm{~B}\end{array}$ & 58,02 \\
\hline Arang sekam & $\begin{array}{c}66,2 \mathrm{~b} \\
\mathrm{~B}\end{array}$ & $\begin{array}{c}55,9 \mathrm{a} \\
\mathrm{A}\end{array}$ & 61,05 \\
\hline Gamping & $\begin{array}{c}57,9 \text { a } \\
\mathrm{A}\end{array}$ & $\begin{array}{c}55,84 \text { a } \\
\mathrm{A}\end{array}$ & 56,81 \\
\hline Rerata & 59,79 & 57,9 & \\
\hline
\end{tabular}


memiliki sifat-sifat ini. Bahan pembawa yang bersifat porous dengan kemampuan menyerap uap air rendah akan memiliki kelembaban yang rendah dibandingkan dengan bahan pembawa yang mudah menyerap uap air. Hal ini akan mencegah spora FMA untuk menyerap air dan dapat menunda perkecambahan spora sebelum diaplikasikan. Selain itu, tingkat kelembaban yang rendah dapat mengurangi kemungkinan resiko kontaminasi oleh bakteri atau fungi lain yang dapat merusak spora FMA. Jenis bahan pembawa yang baik akan mampu mempertahankan viabilitas spora FMA selama masa penyimpanan sehingga apabila diaplikasikanmaka spora yang disimpan ini masihmampu berkecambah dan menginfeksi akar tanaman inangnya.

Secara umum Tabel 2 menunjukkan persen infeksi akar yang diperoleh dalam penelitian ini berkisar $54,1 \%$ - 66,2 \%, dan berdasarkan pengelompokkan tingkat infeksi akar oleh FMA yang dikemukakan oleh Rajapakse dan Miller (1992) dalam Nusantara dkk. (2012), presentase kolonisasi akar yang diperoleh dalam penelitian ini tergolong tinggi. Dengan demikian batuan gamping dapat menjadi salah satu alternatif yang ekonomis untuk penyimpanan/pengemasan FMA selain zeolit dan arang sekam.

Selain berkaitan dengan bahan pembawa yang dapat mempertahankan viabilitas dan infektivitas spora FMA selama masa penyimpanan, tingkat kolonisasi akar oleh FMA juga dapat dipengaruhi oleh kondisi tanah. Pada penelitian ini, tanah yang digunakan. memiliki kandungan P tersedia yang rendah (Tabel 1) yang memungkinkan FMA yang diaplikasikan mampu berkembang dengan baik termasuk kemampuannnya dalam menginfeksi akar inangnya. Tingkat infeksi akar yang tinggi mencerminkan FMA mampu berasosiasi dengan baik dengan inangnya. Beberapa studi terdahulu telah melaporkan bahwa kandungan P tersedia tanah yang tinggi umumnya dapat berdampak buruk terhadap kolonisasi FMA (Grant et al. 2004; Javot et al. 2007, Smith et al., 2011).

\section{Kandungan P jaringan}

Hasil analisis statistik menunjukkan bahwa terjadi interaksi yang nyata antara jenis bahan pembawa dan lama simpan terhadap kandungan $\mathrm{P}$ jaringan. Pada lama simpan 4 bulan, bahan pembawa

Tabel 3. Kandungan P jaringan jagung dengan pemberian FMA yang dikemas menggunakan beberapa jenis bahan pembawa dan lama simpan yang berbeda.

\begin{tabular}{lccc}
\hline \multirow{2}{*}{ Jenis Bahan Pembawa } & \multicolumn{2}{c}{ Lama Simpan } & \multirow{2}{*}{ Rerata } \\
\cline { 2 - 3 } Zeolit & \multicolumn{2}{c}{ Kandungan P jaringan (\%) } & \\
& $0,65 \mathrm{a}$ & $0,77 \mathrm{~b}$ & 0,71 \\
Arang sekam & $\mathrm{A}$ & $\mathrm{A}$ & \multirow{2}{*}{0,82} \\
& $0,89 \mathrm{~b}$ & $0,76 \mathrm{a}$ & \multirow{2}{*}{0,71} \\
Gamping & $\mathrm{B}$ & $\mathrm{A}$ & \\
& $0,71 \mathrm{a}$ & $0,71 \mathrm{a}$ & \\
\hline Rerata & $\mathrm{A}$ & $\mathrm{A}$ & 0,74 \\
\hline
\end{tabular}

Keterangan: Angka-angka yang diikuti oleh huruf yang sama adalah berbeda tidak nyata pada uji DMRT 5\%. Huruf kapital menyatakan perbandingan menurun, huruf kecil menyatakan perbandingan mendatar 
arang sekam memberikan kandungan P jaringan yang lebih tinggi dibandingkan dengan bahan pembawa zeolit dan gamping. Pada lama simpan 6 bulan, kandungan $P$ jaringan relatif tidak berbeda (Tabel 3).

Lebih tingginya kandungan $\mathrm{P}$ jaringan pada perlakuan bahan pembawa arang sekam dengan lama simpan 4 bulan diduga berkaitan dengan tingkat kolonisasi akar yang juga cenderung lebih tinggi pada jenis bahan pembawa arang sekam dengan lama simpan 4 bulan (Tabel 2). Pada lama simpan 6 bulan, bahan pembawa zeolitmemberikanP jaringan sedikit lebih tinggi dengan dibandingkan dengan arang sekam dan gamping.

Pada penelitian ini tingkat kolonisasi akar yang diperoleh tergolong tinggi maka hal ini dapat berkontribusi positif terhadap serapan hara. Apabila tingkat kolonisasi akar tinggi maka makin besar pula kemungkinan penyerapan dan transfer hara khususnya P dari FMA ke inangnya. Menurut Smith et al. (2011), meningkatnya serapan hara P oleh FMA dapat terjadi melalui beberapa mekanisme yaitu pertumbuhan miselia yang ekstensif sehingga memperluas bidang eksplorasi hara, kemampuan FMA dalam mineralisasi P organik melalui sekresi enzim fosfatase, dan melalui acidifikasi rhizosfer pada tanah-tanah dengan $\mathrm{pH}$ netral atau pada tanah calcarosol sehingga membuat $\mathrm{P}$ lebih mudah larut.

\section{Bobot kering biomassa}

Hasil analisis statistik menunjukkan perlakuan jenis bahan pembawa dan lama simpan tidak memberikan pengaruh yang signifikan terhadap bobot kering biomassa (Tabel 4). Hal ini menunjukkan bahwa jenis bahan pembawa yang diuji memiliki kemampuan yang relatif sama dalam mempertahankan viabilitas dan infektivitas spora FMA sehingga spora yang diaplikasikan masih mampu berkecambah dan menginfeksi akar serta memilki efektivitas yang baik dalam mendukung pertumbuhan tanaman inangnya.

Bila dikaitkan dengan kandungan P jaringan, perlakuan bahan pembawa arang sekam dengan lama simpan 4 bulan memiliki kandungan $P$ jaringan yang lebih tinggi dibandingkan dengan perlakuan bahan pembawa lain, namun memberikan pertumbuhan tanaman yang tidak berbeda nyata dengan perlakuan lain. Diduga perlakuan bahan pembawa arang sekam dengan lama simpan 4 bulan maupun pada perlakuan yang lain telah mampu memenuhi kebutuhan hara P bagi tanaman sehingga walaupun terjadi peningkatan $\mathrm{P}$

Tabel 4. Rerata jumlah spora FMA, bobot kering biomassa dan bobot tongkol

\begin{tabular}{lcccc}
\hline Bahan pembawa & Lama simpan & $\begin{array}{c}\text { Jumlah spora } \\
(100 \mathrm{~g} \text { tanah })^{\text {tn }}\end{array}$ & $\begin{array}{c}\text { Bobot kering } \\
\text { biomassa }(\mathrm{g})^{\text {tn }}\end{array}$ & $\begin{array}{c}\text { Bobot tongkol } \\
(\mathrm{g})^{\text {tn }}\end{array}$ \\
\hline Zeolit & 4 bulan & & & \\
Arang sekam & & 357 & 39,77 & 216,7 \\
Gamping & & 377 & 32,5 & 220 \\
\hline & 321 & 35,7 & 213,3 \\
\hline Zeolit & 6 bulan & 529 & 34,03 & 226,7 \\
Arang sekam & & 490 & 34,3 & 213,3 \\
Gamping & & 354 & 35 & 223,3 \\
\hline
\end{tabular}

$\mathbf{t n}=$ hasil analisis statistik faktor jenis bahan pembawa dan lama simpan tidak berpengaruh nyata 
jaringan pada perlakuan arang sekam dengan lama simpan 4 bulan hal ini tidak berkontribusi terhadap peningkatan pertumbuhan tanaman dan akumulasi bahan kering tanaman. Menurut Havlin et al. (2005), apabila level hara pada tanaman telah berada pada kategori cukup maka peningkatan input (pupuk) dapat meningkatkan kandungan hara jaringan namun tidak berkontribusi positifterhadap peningkatan hasil tanaman.

\section{Bobot tongkol}

Hasil analisis statistik menunjukkan perlakuan jenis bahan pembawa zeolit, arang sekam dan gamping dengan lama simpan 4 bulan dan 6 bulan tidak berpengaruh nyata terhadap bobot tongkol jagung (Tabel4). Tidak berbeda nyatanya pengaruh perlakuan yang diuji terhadap bobot tongkol dapat dikaitkan dengan akumulasi bahan kering tanaman yang juga tidak berbeda pada perlakuan yang diuji. Pembentukan bagian generati berkaitan erat dengan pertumbuhan vegetatif. Perumbuhan vegetatifyang berjalan baik akan menghasilkan fotosintat yang cukup utntuk pembentukan komponen hasil tanaman.

Tidak beerbeda nyatanya jenis bahan pembawa zeolit, arang sekam dan gamping dengan lama simpan 4 dan 6 bulan terhadap pertumbuhan dan hasil jagung menunjukkan bahwa ketiga bahan yang diuji memiliki kemampuan yang relatif sama dalam mempertahankan viabilitas spora FMA selama masa penyimpan sehingga infektivitas maupun efektivitasnya tetap terjaga saat diaplikasikan ke tanaman.

\section{KESIMPULAN}

Pada lama simpan 4 bulan arang sekam memberikan tingkat kolonisasi akar dan P jaringan yang lebih tinggi, dan pada lama simpan 6 bulan kolonisasi akar dan $\mathrm{P}$ jaringan tertinggi adalah pada bahan pembawa zeolit. Ketiga bahan pembawa yang diuji (arang sekam, zeolit dan gamping) dengan lama simpan 4 dan 6 bulan memberikan koloniasi akar yang tergolong tinggi, memberikan jumlah spora, bobot kering biomassa dan bobot tongkol yang tidak berbeda nyata. Arang sekam, zeolit dan gamping dapat dijadikan sebagai bahan pembawa inokulan FMA dengan lama simpan 6 bulan .

\section{UCAPAN TERIMA KASIH}

Penelitian ini merupakan bagian dari penelitian yang didanai oleh Litbang Pertanian Kementerian Pertanian melalui Hibah Kompetisi KP4S

\section{DAFTAR PUSTAKA}

Anwarudin, S., M.J. Jumjunidang, dan Y. Herizal. 2004. Penyiapan kapsul cendawan mikoriza arbuskula untuk mempertahankan daya multiplikasi dan infektivitas. Jurnal Hortikultura. 16,(2): 129-133.

Al-Karaki, G., B. McMichael, and J. Zak. 2003. Field response of wheat to arbuscular mycorrhizal fungi and drought stress. Mycorrhiza doi.10.1007/s00572-003-0265-2.

Brady, N.C. and R.R., Weil. 2000. The Nature and Properties of Soils. Pearson Prentice Hall Press. Upper Saddle River, New Jersey.

Brundrett, M. 1991. Mycorrhizas in Natural Ecosystem. In Advances in Ecological Research Vol.21, P 171-313. Begon, M, Fitter, A.H. Macfayden, A. (Eds). Academic Press Limited, London.

Brundrett, M. C., N. Bougher, B. Dell, T. Grove, and N. Malajczuk. 1996. Working with Mycorrhiza in Forestry and Agriculture. Canberra, Australia: 
Australian Centre for International Agricultural Research. 374p

Ishaq, L., A.S.J. Adu Tae, M. A. Airthur, and P.O. Bako. 2017. Abundane of arbuscular Mycorrhizal Fungi assocaietd with corn planted with traditional and more modern farming systems in kupang, east Nusa Tenggara Timur, Indonesia. Biodiversitas 18 (3); 887-892

Ishaq, L.F. 2018. Presence of arbuscular mycorrhizal in maize plantation land cultivated with traditional and more improved land management. Asian Journal of Agriculture 2 (1); $20-24$

Fang, G., F. S. Zhang, X. L. Li, C. Y. Tian, and C. Tang. 2002. Improved tolerance of maize palnts to salt stress by arbuscular mycorrhizal is related to higher accumulation of soluble sugar. Mycorriza 12: 185-190

Farzaneh, M., H. Vierhellig, A. Lossa, and H.P. Kaul. 2011. Arbuscularmycorrhizal enhances nutrient uptake in cheakpea. Plant Soil Environment 10: 465-470

Garg, N., and R. Pandey. 2015. Effectiveness of native and exotic arbuscular mycorrhizal fungi on nutrient uptake and ion homeostasis in saltstressed Cajanus cajan L. (Mill sp..) genotypes. Mycorrhiza 25: 165-180)

Grant, C., S. Biffman, M. Montreal, C. Plenchette, and C. Morel. 2004. Soil and Fertilizer Phophorus: Effect on plant P supply and mycorrhizal development. C.J. Plant Sci: 3-14

Havlin, J.L., J.D. Beaton, S.L. Tisdale, and W.L. Nelson. 2005. Soil Fertility and Fertlizer. An Introduction to Nutrient Management. Seventh Edition. Pearson Education Inc. Upper Saddle River, New Jersey.

Javot, H. N. Pumplin, and M.J. Harrison. 2007. Phosphate in the arbuscular mycorrhizal symbiosis transport properties and regulatory roles. Plant cell Environ 30: 310-322
Luo, N., X. Li. A.Y. Chen, L.J. Zhang, H.M. Zhao, L. Xiang, Q. Y. Chai, C.H. Mo, M. H. Wong, and H. Li. 2017. Does arbuscular mycorrhizal fungus affect cadmium uptake and chemical forms in rice at different growth stages. Science of the Total Environment; 1564-1572

Leytem, A.B. and R.L. Mikkelsen. 2005. The nature of phosphorus in calcareous soils. Better Crops. 89 (2): 11-13

Marschner, H. and B. Dell. 1994. Nutrient uptake in mycorrhizal symbiosis. Plant and Soil 159: 89-102

Maria, R.K., and R.B. Felinov. 2017. Development of carrier based in Vitro produced arbuscular mycorrhizal (AM) fungal inocula for organic agriculture. Annals of Advanced Agricultural Sciences 1(1): 26-37

Muchane, M., T. Kuyper, J. Jefwa, M. Pulleman, and B. Vanlauewe. 2013. Impact of arbuscular mycorrhizal fungi and earthworms on aggregate stability. Abstract International Conference on Mycorrhiza. Department of Biotechnology Ministry of Science and Technology Government of India, New Delhi, India

Nurbaity, A., D. Herdiyanto, dan O. Mulyani. 2009. Pemanfaatan bahan organik sebagai bahan pembawa inokulan fungi mikoriza arbuskula. Jurnal Biologi XIII (1): 7-11

Nurbaity, A., A. Setiawan, dan O. Mulyani. 2011. Efektivitas arang sekam sebagai bahan pembawa pupuk hayati mikoriza arbuskula pada produksi sorgum. Jurnal Agrinimal 1(11): $1-6$

Pellegrino, F., S. Bedini, L. Avio, E. Bonari, and M. Giovanetti. 2011. Field inoculation effectiveness of native and exotic arbuscular mycorrhizal fungi in a Mediterranean agricultural soil. Soil Biology and Biochemistry 43: 367-376

Rapparini, F and J. Penuelas. 2014. Mycorrhizal fungi to alleviate drought stresses on plant growth In Use of microbes for the alleviation of soil 
stresses.P21-42.M.Miransari(Eds).DOI: 10.1007/ 978-1-4614-9466-9.2. Springer.New York

Siregar, Z.K., Fikrinda, dan T. Alvisyahrin. 2020. Pengaruh media pembawa dalam perbanyakan spora fungi mikoriza arbuskula. Jurnal Mikologi $4(1) ; 125-133$

Steinberg, P.D., and M.C Rillig. 2003. Differential decomposition of arbuscular mycorrhizal fungal hyphae and glomalin. Soil Biology and Biochemistry 35(1): 191-194
Smith, S. E. and D.J. Read. 2008. Mycorrhizal Symbiosis. New York, USA: Elsevier. 787 p.

Smith, S.E., I. Jacobsen, M. Grondlund, and F.A. Smith. 2011. Role of arbuscular mycorhizas in plant phosphorus nutrition: interactions between pathways and phosphorus uptake in arbuscular mycorrhizal roots have important implications for understanding and manipulating phosphorus acquisition. Plant Physiology 25: 1050-1057 